\title{
Trigonella foenum (Fenugreek) Induced Apoptosis in Hepatocellular Carcinoma Cell Line, HepG2, Mediated by Upregulation of p53 and Proliferating Cell Nuclear Antigen
}

\author{
Mahmoud I. M. Khalil, ${ }^{1}$ Mohamed M. Ibrahim, ${ }^{2,3}$ \\ Gehan A. El-Gaaly, ${ }^{2}$ and Ahmed S. Sultan ${ }^{4}$ \\ ${ }^{1}$ Zoology Department, Faculty of Science, Alexandria University, Alexandria 21511, Egypt \\ ${ }^{2}$ Botany and Microbiology Department, Science College, King Saud University, P.O. Box 2455, Riyadh 11451, Saudi Arabia \\ ${ }^{3}$ Botany and Microbiology Department, Faculty of Science, Alexandria University, Alexandria 21511, Egypt \\ ${ }^{4}$ Department of Biochemistry, Faculty of Science, Alexandria University, Alexandria 21511, Egypt \\ Correspondence should be addressed to Ahmed S. Sultan; dr_asultan@alexu.edu.eg
}

Received 20 February 2015; Revised 11 April 2015; Accepted 16 April 2015

Academic Editor: Sandra Marmiroli

Copyright ( 2015 Mahmoud I. M. Khalil et al. This is an open access article distributed under the Creative Commons Attribution License, which permits unrestricted use, distribution, and reproduction in any medium, provided the original work is properly cited.

\begin{abstract}
Hepatocellular carcinoma (HCC) is one of the most common cancers worldwide and most current therapies are of limited efficacy. Trigonella foenum (Fenugreek) is a traditional herbal plant with antitumor activity, although the mechanisms of its activity remain unclear. Herein, a crude methanol extract was prepared from Fenugreek seeds (FCE) and its anticancer mechanism was evaluated, using HepG2 cell line. Growth-inhibitory effect and apoptosis induction of HepG2 cells were evidenced by MTT assay, cell morphology alteration, apoptosis enzyme-linked immunosorbent assay, flow cytometric analysis, caspase- 3 activity, and expression of p53, proapoptotic protein, Bax, and proliferating cell nuclear antigen (PCNA) after $(100 \sim 500 \mu \mathrm{g} / \mathrm{mL}) \mathrm{FCE}$ treatment for $48 \mathrm{~h}$. Furthermore, FCE was analyzed by Chromatography-Mass Spectrometry (GC/MS). Our results revealed that FCE treatment for $48 \mathrm{~h}$ showed a cytotoxic effect and apoptosis induction in a dose-dependent manner that was mediated by upregulation of p53, Bax, PCNA, and caspase-3 activation in HepG2 cells. GC-MS analysis of FCE showed the presence of fourteen bioactive compounds such as Terpenoids and Flavonoids, including two main constituents with anticancer activity, Squalene and Naringenin (27.71\% and $24.05 \%)$, respectively. Our data introduced FCE as a promising nontoxic herbal with therapeutic potential to induce apoptosis in HepG2 cells through p53, Bax, and PCNA upregulation in caspase-3 dependent manner.
\end{abstract}

\section{Introduction}

Hepatocellular carcinoma (HCC) is the sixth most common cancer worldwide, accounting for $9.1 \%$ of all cancers and an estimated incidence of 746,000 new cases every year. It is considered to be the third cause of cancer related deaths $(692,000$ cases). The highest incidence rates of HCC (around $85 \%$ of cases) are present in East Asia and sub-Saharan Africa [1]. The prognosis for liver cancer is very poor (overall ratio of mortality to incidence of 0.95 ), and as such the geographical patterns in incidence and mortality are similar.

In Egypt, there is a growing incidence of HCC (10$120 / 100,000$ ) [2], which represents the leading cause of death from all other cancer sites [3]. HCC has nearly doubled over the last decade among patients with chronic liver disease (CLD) [4]. HBV and HCV infections are the most important risk factors associated with progression from chronic hepatitis to cirrhosis and, eventually, to HCC. In spite of the advances made in HCC diagnosis treatment, intervention strategies are still badly warranted, including chemopreventive agents that act on the early molecular events of cancer initiation by preventing, delaying, or reversing epithelial-mesenchymal transition, as well as those that act as therapeutic agents for cancer progression $[5,6]$. Using chemopreventive agents that have low toxicity and high efficiency in inhibiting tumor growth and are involved in decrease of carcinogenic agents effects is very promising target for cancer therapy [7]. 
Recently, increasing attention has been focused to identify the naturally occurring anticancer agents, particularly those present in dietary and medicinal plants due to their bioactive substances $[8,9]$. Most of these bioactive substances exert their cancer chemotherapeutic activity by modulating signal transduction pathways that are involved in cell cycle progression, proliferation, and triggering apoptotic cell death. In addition, induction of tumor suppressor genes in tumor cells has become promising therapeutic indicator for tumor treatment response in employing a plant derived-bioactive substance to decrease breast cancer mortality.

In many developed countries herbal medicines are achieving attractiveness as alternative and courtesy therapies [10]. Some of the plants are used as food or medicine. These plants display varied kinds of biological and pharmacological activities. Fenugreek (Trigonella foenum-graecum L.) is a legume crop that is used as a spice in cooking and in small quantities is categorized as "Generally Recognized as Safe" by the U.S. Food and Drug Administration [11]. Due to its amazing therapeutic and medical properties it is one of the oldest medicinal plants known and has long been recognized as a traditional medicine in different parts of the world and in Egypt as well $[12,13]$. Recent reports showed that the seeds of the plant have been used as an old-style medicine for abundant circumstances, because it contains different active chemical constituents, including steroidal sapogenins [14], dietary fiber [13], galactomannans [15], antioxidants, and amino acids such as 4-hydroxyisoleucine, which possess antidiabetic [16], hypocholesterolemic, and hypoglycemic properties [17] that show a potential treatment as antileukemic, antipyretic [18], and antifertility activity [19], obesity, diabetes, and cancer treatment [20, 21].

Flavonoids have high pharmacological action and excessive anxiety in these constituents has been stimulated by the prospective health benefits arising from the antioxidant activity of these polyphenolic compounds [22]. The seed extract contains another bioactive compound, which is called diosgenin that induces apoptosis in HT-29 human colon cancer cells [23]; besides it plays a role in osteoclastogenesis, invasion, and proliferation inhibition through the downregulation of Akt, I kappa B kinase activation, and NF kappa Bregulated gene expression in tumor cells [24]. Furthermore, some constituent of alkaloids, "trigonelline," has a potential role in cancer treatment [25]. Another active agent identified in Fenugreek is Protodioscin, which induces apoptosis in the leukemic cell line HL-60 [26].

The prototypic molecular change associated with cancer is mutation of tumor suppressor $p 53$, which is inactivated in $50 \%$ of human cancers [27]. The p53 protein is a key regulator of cell cycle arrest and apoptosis and is controlled by a complex network of posttranslational modifications that regulate its activity, stability, and molecular interactions [28]. In HCC, p53 mutation occurs late in hepatocarcinogenesis [29]. However, the relationship between p53WT expression and differentiation grade has not been well described. Intervention to restore wild type $p 53$ activity is an alternative approach for HCC treatment. Recently, many studies from our laboratory and others focused on p53 role in the pathogenesis and development, diagnosis and treatment, and therapeutic effects and prognosis of HCC [30-32].

Proliferating cell nuclear antigen (PCNA), an essential regulator of the cell cycle, is a $36 \mathrm{kDa}$ molecule, which is highly conserved among species. PCNA is an evolutionally well-conserved protein found in all eukaryotic species from yeast to humans, as well as in archaea. Its functions are related to vital cellular processes such as DNA replication, chromatin remodeling, DNA repair, sister chromatid cohesion, and cell cycle control [33]. PCNA role and interactions are modulated by posttranslational regulation, whose exact mechanisms are controversial and not completely understood. Many reports showed posttranslational regulation of PCNA modifications, including [34] phosphorylation, acetylation [35, 36], and methyl esterification [37]. In addition, PCNA is important to determine its role in proliferative activity in different tumors including HCC [38].

The present study was aimed at evaluating the therapeutic effect of Fenugreek crude extract (FCE) against immortalized HCC cell line, HepG2. In addition, we focused on the role of FCE on p53, Bax, and PCNA protein expression levels as one of the key proteins involved in apoptosis induction in HepG2 cell line.

\section{Materials and Methods}

2.1. Plant Material and Extraction Procedure. Trigonella foenum-graecum seeds were bought fresh from local market, Alexandria, Egypt, and the purity and quality of the seeds were investigated by Drs. M. M. Ibrahim and G. A. ElGaaly who are experts in this field. The air-dried seeds were ground multiple times with an electric grinder. $15 \mathrm{gm}$ of the power-driven seeds was weighted, transferred to flask, treated with the methanol until the powder was fully immersed, and refluxed for $24 \mathrm{~h}$ at $50^{\circ} \mathrm{C}$. The resulting supernatant was filtered and evaporated. The seed residue was soaked and refluxed with 1 liter each of hexane, petroleum ether, ethyl acetate, and chloroform, respectively. The resulting filtered supernatants were combined and evaporated.

2.2. GC-MS Analysis. The GC-MS analysis was carried out using a Clarus 500 PerkinElmer (Auto system XL) Gas Chromatograph equipped and coupled to a mass detector Turbo Mass Gold, PerkinElmer Turbo Mass 5.1 spectrometer with an Elite-1 (100\% dimethylpolysiloxane), $30 \mathrm{~m} \times 0.25 \mathrm{~mm} \mathrm{ID} \times$ $1 \mu \mathrm{m}$ of capillary column. The instrument was set to an initial temperature of $110^{\circ} \mathrm{C}$ and maintained at this temperature for $2 \mathrm{~min}$. At the end of this period, the oven temperature was rose up to $280^{\circ} \mathrm{C}$, at the rate of an increase of $5^{\circ} \mathrm{C} / \mathrm{min}$, and maintained for $9 \mathrm{~min}$. Injection port temperature was ensured as $250^{\circ} \mathrm{C}$ and helium flow rate as one $\mathrm{mL} / \mathrm{min}$. The ionization voltage was $70 \mathrm{eV}$. The samples were injected in split mode as 10:1. Mass spectral scan range was set at 45$450(\mathrm{~m} / \mathrm{z})$.

2.3. Identification of Phytocompounds of FCE. Using the database of Wiley $275 \mathrm{~L}$. library and comparing the spectrum 
obtained through GC-MS compounds present in the plants sample were identified. Interpretation on mass-spectrum GC-MS was conducted using the database of Wiley $275 \mathrm{~L}$. The spectrum of the unknown components was compared with the spectrum of known components stored in the Wiley 25 L. library. The name, molecular weight, and structure of the components of the test materials were ascertained.

2.4. Cell Culture. HepG2 cells were obtained from American Type Culture Collection (Rockville, MD, USA) and maintained in Dulbecco's modified essential media (DMEM, Gibco) supplemented with 10\% Fetal Bovine Serum (FBS), $100 \mathrm{Units} / \mathrm{mL}$ penicillin, and $100 \mu \mathrm{g} / \mathrm{mL}$ streptomycin at $37^{\circ} \mathrm{C}$ in a $5 \% \mathrm{CO}_{2}$ atmosphere.

2.5. Cell Cytotoxicity (MTT Assay) of HepG2 Cell Line. HepG2 cells were cultured as described above till mid-log phase. Cells were harvested and resuspended in growth media to make a stock cell suspension containing 20,000 cells $/ \mathrm{mL}$. $100 \mu \mathrm{L}$ of this stock cell suspension was added to the wells of a 96-well plate. The cells were allowed to attach and grow for $24 \mathrm{~h}$. The crude extract was weighed and diluted with DMSO to make a $100 \mathrm{mg} / \mathrm{mL}$ stock solution. This stock solution was further diluted with culture media to make a secondary working solution. The working solution was added to the wells such that final concentrations of range $0 \sim 2000 \mu \mathrm{g} / \mathrm{mL}$ of FCE were obtained. Each experiment was performed in triplicate in parallel for each concentration. Controls were performed in which only culture media and DMSO were added. The cells were then incubated at $37^{\circ} \mathrm{C}$ in a $5 \% \mathrm{CO}_{2}, 95 \%$ air atmosphere. After $72 \mathrm{~h}$ of incubation, the culture medium was removed and the cells were washed twice with phosphate buffered saline (PBS). Then $20 \mu \mathrm{L}$ of $5 \mathrm{mg} / \mathrm{mL}$ MTT [3-(4,5-dimethylthiazol-2-yl)-2,5-diphenyltetrazolium bromide] was added to each well. The cells were further incubated at $37^{\circ} \mathrm{C}$ for $4 \mathrm{~h}$. The supernatant was discarded and $100 \mu \mathrm{L}$ of DMSO was added to each well. The mixture was shaken on a microvibrator for $5 \mathrm{~min}$ and the absorbance was measured at $570 \mathrm{~nm}(A)$ that served as a measure of cell viability. Inhibition ratio $(I \%)$ was calculated using the following equation: Formula $I \%=\left(A_{\text {control }}-A_{\text {treated }}\right) / A_{\text {control }} \times 100$.

2.6. Morphological Analysis. Morphological observation of HepG2 cells treated with FCE was done to determine the changes induced by treatment. All the cells were exposed to increasing concentrations (100 500 $\mu \mathrm{g} / \mathrm{mL}$ range) of FCE for $48 \mathrm{~h}$ and cell images were taken using an inverted phase contrast microscope at 200x magnification.

2.7. Apoptosis Enzyme-Linked Immunosorbent Assay. Cells were seeded at a density of $2 \times 10^{4} /$ well in a 96 -well plate and incubated for $24 \mathrm{~h}$. Media were changed to media containing the tested extract $(100 \sim 500 \mu \mathrm{g} / \mathrm{mL}$ range) dose. Cells were then incubated for extra $24 \mathrm{~h}$. An ELISA assay was performed, using Cell Death Detection ELISAPLUS kit (cat. number 11774425001) (Roche-Applied Science, Indianapolis, USA) that measures histone release from fragmented DNA in apoptotic cells. The assay is based on the quantitative "sandwich enzyme immunoassay" principle using mouse monoclonal antibodies directed against DNA and histones. This allows the specific determination of mono- and oligonucleosomes in the cytoplasmic fraction of cell lysates. Cells were lysed with $200 \mu \mathrm{L}$ lysis buffer for $30 \mathrm{~min}$ at room temperature. The lysate was subjected to centrifugation for $10 \mathrm{~min}$ and $200 \mu \mathrm{L}$ of supernatant was collected, of which $20 \mu \mathrm{L}$ was incubated with anti-histone biotin and anti-DNA peroxidase at room temperature for $2 \mathrm{~h}$. After washing with incubation buffer three times, $100 \mu \mathrm{L}$ of substrate solution $\left(2,2^{\prime}\right.$-azinodi(3-ethylbenzthiazoline-sulphuric acid)) was added to each well and incubated for $15-20 \mathrm{~min}$ at room temperature. The absorbance was measured using an ELISA reader (Jenway Spectrophotometer, UK). Each assay was done in triplicate and standard deviation was determined.

2.8. Flow Cytometric Analysis. Cells were seeded at a density of $3-5 \times 10^{5} / 10-\mathrm{cm}^{2}$ plate and incubated for 24 before treatment. Media were changed to media containing 100 $500 \mu \mathrm{g} / \mathrm{mL}$ range of FCE for $48 \mathrm{~h}$. Cells were harvested by trypsinization, washed with PBS, and fixed with ice-cold $70 \%$ ethanol while vortexing. Finally, the cells were washed and resuspended in PBS containing $5 \mu \mathrm{g} / \mathrm{mL}$ RNase-A (Sigma, St. Louis, MO, USA) and $50 \mu \mathrm{g} / \mathrm{mL}$ propidium iodide (Sigma, St. Louis, MO, USA) for cell cycle analysis. Cell cycle analysis was performed, using FACScan Flow Cytometer (Becton Dickson) according to the manufacturer's protocol.

2.9. Caspase-3 Activity. Caspase-3 activity was assayed according to manufacturer's protocol of colorimetric assay kit (BioVision, Inc., CA, USA) that provides a quick and efficient detection of caspase- 3 activity in cell lysates and in purified preparations of caspase- $3.5 \times 10^{6}$ cells were treated with or without $100 \sim 500 \mu \mathrm{g} / \mathrm{mL}$ FCE and lysed in $100 \mu \mathrm{L}$ lysis buffer containing $10 \mathrm{mM}$ HEPES (4-(2-hydroxyethyl)1-piperazineethanesulfonic acid), $\mathrm{pH}$ 7.4, $2 \mathrm{mM}$ EDTA, 0.1\% CHAPS (3-[(3-cholamidopropyl)dimethylammonio]1-propanesulfonic acid, $5 \mathrm{mM}, 350 \mu \mathrm{g} / \mathrm{mL}$ PMSF (phenylmethanesulfonylfluoride or phenylmethylsulfonyl fluoride), and $5 \mathrm{mM}$ DTT (Dithiothreitol). Cells were homogenized by three cycles of freezing and thawing and then centrifuged to remove the cellular debris. Each sample was then incubated in buffer containing $10 \mathrm{mM}$ HEPES, pH 7.4, 2 mM EDTA, 0.1\% CHAPS, and $5 \mathrm{mM}$ EDTA supplemented with its substrate (Ac-Asp-Glu-Val-Asp-AFC) Ac-DEVD-AFC for $1 \mathrm{~h}$ at room temperature and then reaction was stopped with $1 \mathrm{~N} \mathrm{HCl}$. OD405 was measured using a spectrophotometer (Jenway Spectrophotometer, UK). Each assay was done in triplicate and standard deviation was determined.

2.10. Western Blotting Analysis. Cells were plated in 6-well dishes for western blotting analysis. Cells were lysed with a $1 \%$ NP-40 containing buffer supplemented with a 1x cocktail of protease inhibitors (Complete Mini, Roche, Mannheim, Germany) and phosphatase inhibitors (phosphatase inhibitor cocktail I and II, Sigma) at $4^{\circ} \mathrm{C}$ for $30 \mathrm{~min}$. Lysates were centrifuged at $10,000 \mathrm{~g}$ at $4^{\circ} \mathrm{C}$ for $15 \mathrm{~min}$ and supernatants collected. The protein concentration of the supernatant was 


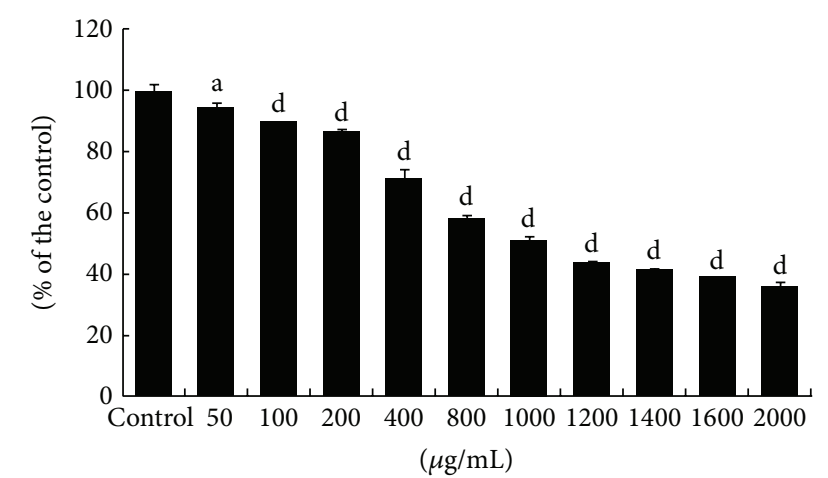

FIGURE 1: Effect of Fenugreek seed crude extract (FCE) on cell viability of HepG2 cells. MTT assay was performed to detect the living cells as described under Section 2. Each data point is an average of results from three independent experiments performed in triplicate and presented as $\mathrm{M} \pm \mathrm{SD}$.

determined using the BCA assay (Pierce, Rockford, IL). Samples were mixed in a ratio of $1: 2$ in Laemmli buffer and denatured by heating at $98^{\circ} \mathrm{C}$ for $5 \mathrm{~min}$. Forty $\mu \mathrm{g}$ of protein was separated on 10\% Tris-SDS-PAGE gels (Bio-Rad Laboratories, Hercules, CA, USA) at $100 \mathrm{~V}$ for $1 \mathrm{~h}$. For western blotting, the separated proteins were electrophoretically transferred onto polyvinylidene difluoride membranes (BioRad Laboratories, Hercules, CA, USA) at $380 \mathrm{~mA}$ for $1 \mathrm{~h}$. Western blot analysis was carried out using specific primary antibodies for p53 and Bax (Santa Cruz Biotechnology, CA, USA) and PCNA and anti-poly(ADP-ribose) polymerase (Cell Signaling Technology, Beverly, MA, USA) antibodies. The expression of $\beta$-actin (Sigma-Aldrich, St. Louis, MO, USA) was used as a normalization control for protein loading. The membranes were blocked with TBS plus 5\% nonfat milk ( $20 \mathrm{mM}$ Tris- $\mathrm{HCl}, \mathrm{pH} 7.6,137 \mathrm{mM} \mathrm{NaCl})$ followed by incubation overnight with primary antibodies diluted in blocking solution for antibodies (1-1000). This was followed by incubation again for $1 \mathrm{~h}$ in the appropriate horseradish peroxidase-conjugated secondary antibodies (Santa Cruz Biotechnology, CA, USA). For detection, an ECL kit was used according to the manufacturer's instructions (Amersham, Buckinghamshire, UK). The corresponding relative density of p53 and PCNA bands was calculated by Quantity One software.

\section{Results}

3.1. Effects of FCE on the Inhibition of HepG2 Cell Proliferation. Exponentially growing HepG2 cell line was cultured continuously in the absence or presence of different concentrations of FCE. The effects of tested FCE on cell growth were assessed by the MTT assay after $48 \mathrm{~h}$ of incubation with FCE as described under Section 2. The concentration of 50\% inhibition of HepG2 cell viability was calculated as $\mathrm{IC}_{50}$, using a Semilogarithmic plotting of the $\%$ of cell viability versus concentration of the tested extract. The $\left(\mathrm{IC}_{50}=1000 \mu \mathrm{g} / \mathrm{mL}\right)$ dose of FCE showed a significant decrease in cell survival of HepG2 cells compared to control group at $48 \mathrm{~h}$ (Figure 1). As shown in Figure 1, treatment by concentrations range
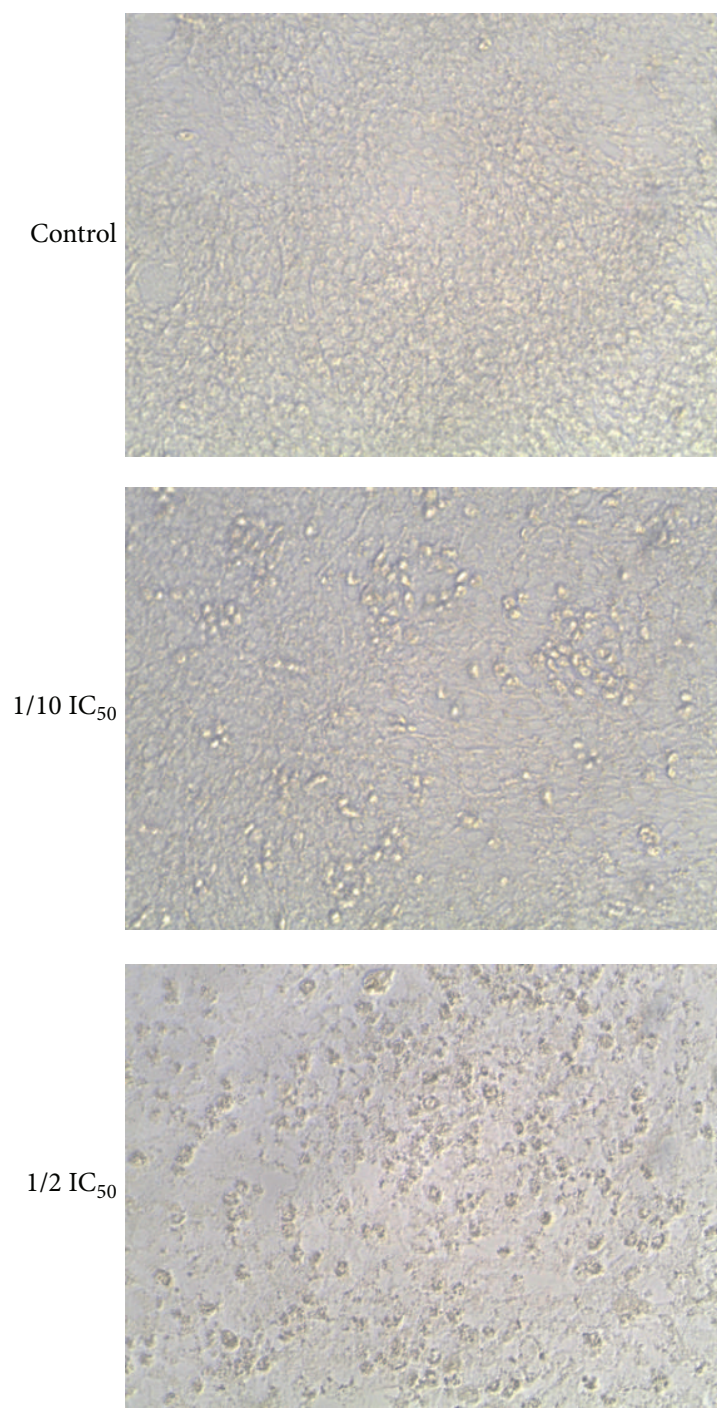

FIGURE 2: Fenugreek seed crude extract (FCE) induced changes in HepG-2 cell line morphology. The results revealed that the control cells showed a typical polygonal and intact appearance, whereas the $100 \sim 500 \mu \mathrm{g} / \mathrm{mL}$ range of FCE-treated cells displayed morphological changes with preapoptotic characteristics. Representative data from three independent experiments are shown, using inverted phase contrast microscope at 200x magnification.

of $0 \sim 2000 \mu \mathrm{g} / \mathrm{mL}$ for $48 \mathrm{~h}$ of FCE showed a significant dose-dependent cytotoxic effects on HepG2 cell line with complete elimination of all cells at a dose over $1000 \mu \mathrm{g} / \mathrm{mL}$ (Figure 1). Our data showed that FCE significantly decreases HepG2 cell viability in dose-dependent manner. Significant decrease of cell viability was observed at $100 \mu \mathrm{g} / \mathrm{mL}$ and above concentrations of FCE compared to control untreated group $(P<0.01$, unpaired $t$-test $)$.

3.2. Morphological Changes. The morphological changes observed in HepG2 treated with or without FCE treatment for $48 \mathrm{~h}$ are shown in Figure 2. Morphological alterations of HepG2 cell line after $(100 \sim 500 \mu \mathrm{g} / \mathrm{mL})$ FCE treatment for $48 \mathrm{~h}$ were observed under phase contrast inverted microscope. The cells indicated the most prominent effects after 


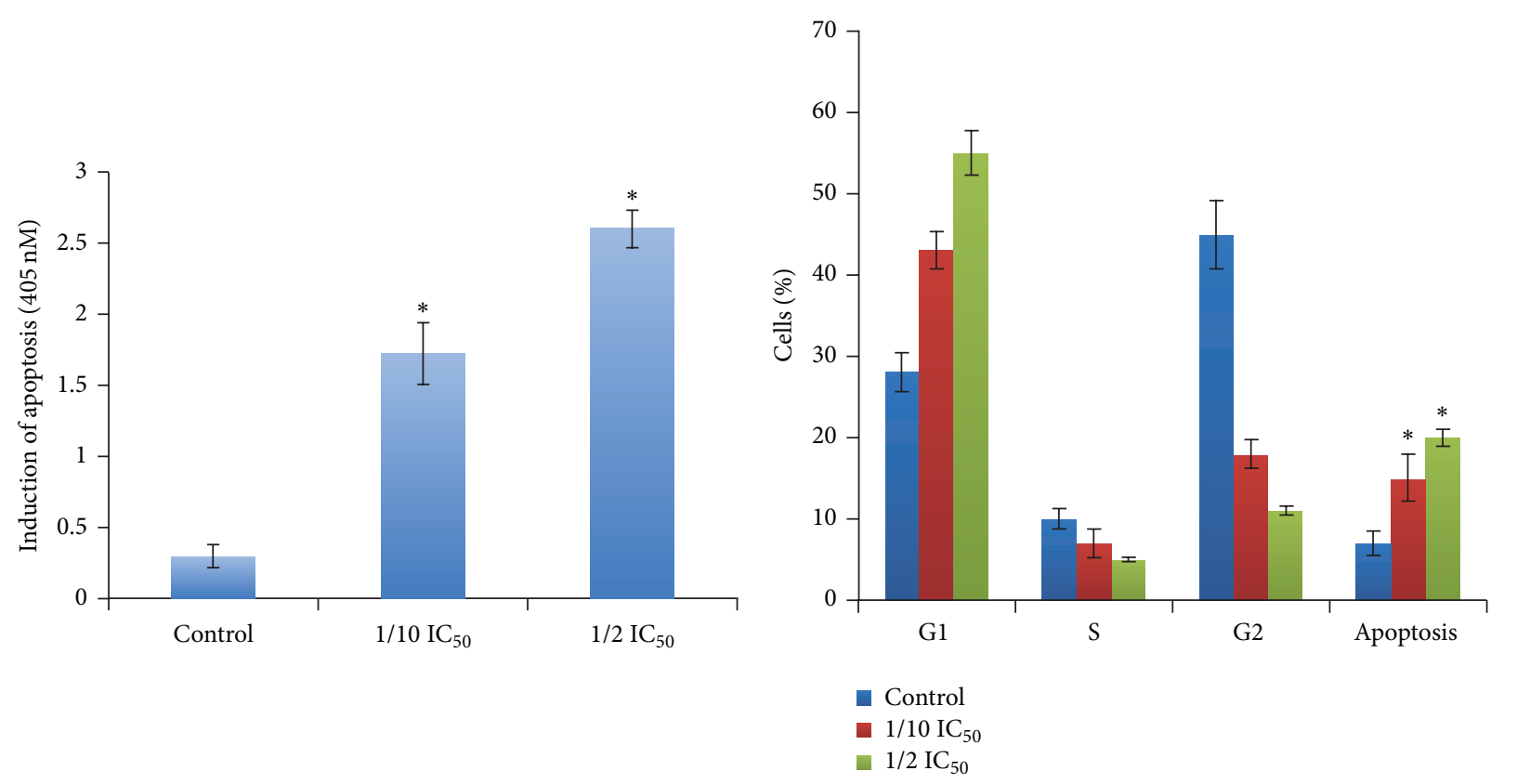

(a)

(b)

FIGURE 3: (a) Apoptosis enzyme-linked immunosorbent assay, ELISA. Apoptosis detection assay was applied to detect apoptosis induction in HepG2 cells after treatment with FCE. Cells were treated with $(100 \sim 500 \mu \mathrm{g} / \mathrm{mL}$ range) FCE for $48 \mathrm{~h}$. Cells without drug treatment were used as controls. ${ }^{*} P<0.05$ as compared to the untreated controls, using the unpaired Student $t$-test. Each data point is an average of three independent experiments and is expressed as $\mathrm{M} \pm \mathrm{SD}$. (b) Flow cytometric analysis of Hep 22 cells after treatment with or without Fenugreek seed crude extract (FCE). Cell cycle analysis shows \% of cell cycle phases of HepG2 cell line treated with or without 100 500 $\mu \mathrm{g} / \mathrm{mL}$ range of FCE for $48 \mathrm{~h} .{ }^{*} P<0.05$ as compared to the untreated controls, using the unpaired Student $t$-test. Each data point was an average of results from three independent experiments performed in triplicate and presented as $\mathrm{M} \pm \mathrm{SD}$.

FCE treatment starting at $24 \mathrm{~h} \sim 48 \mathrm{~h}$. Changes in morphology were found in concentration-dependent manner. Cells exposed to concentration range of $100 \sim 500 \mu \mathrm{g} / \mathrm{mL}$ of FCE for $48 \mathrm{~h}$ altered the normal morphology of the cells and cell adhesion capacity in comparison to control (Figure 2). The effect of FCE on treated cells started at $100 \mu \mathrm{g} / \mathrm{mL}$ in which the cells lost their typical morphology and appeared smaller in size, shrunken, and rounded. Furthermore, treatment of the cells with the same concentrations for $72 \mathrm{~h}$ killed most of the cells (data not shown).

3.3. Apoptosis Enzyme-Linked Immunosorbent Assay, ELISA. Our data indicated that FCE significantly decreased cell viability compared to control cells as shown in Figure 1. It is possible that the decrease in cell viability by FCE treatment as determined by MTT assay could be due to either cell growth arrest or cell death. Understanding the molecular mechanism associated with hepatocellular carcinoma improves screening and treatment of the disease [39]. To investigate if the decrease in cells viability could be due to apoptosis induction, apoptotic assay, using ELISA technique, was performed, which detected histone release from apoptotic cells (Figure 3(a)). HepG2 cells were treated with (100 $500 \mu \mathrm{g} / \mathrm{mL}$ ) FCE and induced apoptosis was determined as indicated by histone release according to manufacturer's protocol compared to untreated, control cells; more details are under Section 2. In addition, cell death was assayed by
Trypan blue staining, which determines membrane integrity (data not shown). FCE-induced cell death was a relatively late event, starting after $48 \mathrm{~h}$ of treatment with treatment by $(100 \sim 500 \mu \mathrm{g} / \mathrm{mL})$ FCE. The number of both the Trypan blue-dead cells and the condensed and fragmented nuclei increased with increasing FCE concentration, confirming that FCE-induced cell death was due to apoptosis induction in HepG2 cells. Furthermore, we performed cell cycle analysis to examine and confirm the effect of FCE treatment on apoptosis induction in HepG2 cells for $48 \mathrm{~h}$ (Figure 3(b)). Consistent with the results of ELISA, cells were treated with or without $(100 \sim 500 \mu \mathrm{g} / \mathrm{mL})$ FCE for $48 \mathrm{~h}$. Our data revealed that a significant increase in apoptotic HepG2 cells at sub-G1 was detected by flow cytometry analysis and the ratio was $\sim 34.9$ and $49.1 \%$, respectively, compared to the untreated control cells. Flow cytometry analysis also showed a significant increase in G1 phase through arresting cells by ratio of $\sim 53.3$ and $65 \%$, respectively, compared to untreated cells as shown in Figure 3(b), indicating that FCE significantly induced apoptosis in HepG2 cells. Induced apoptosis by $500 \mu \mathrm{g} / \mathrm{mL}$ FCE treatment showed more significant effects compared to $100 \mu \mathrm{g} / \mathrm{mL}$ FCE treatment.

3.4. Caspase-3 Activity. One of the key events in apoptosis is the activation of a cascade of intracellular cysteine proteases known as caspases [40]. On proteolytic activation by upstream caspases, caspase- 3 is able to cleave a variety of 


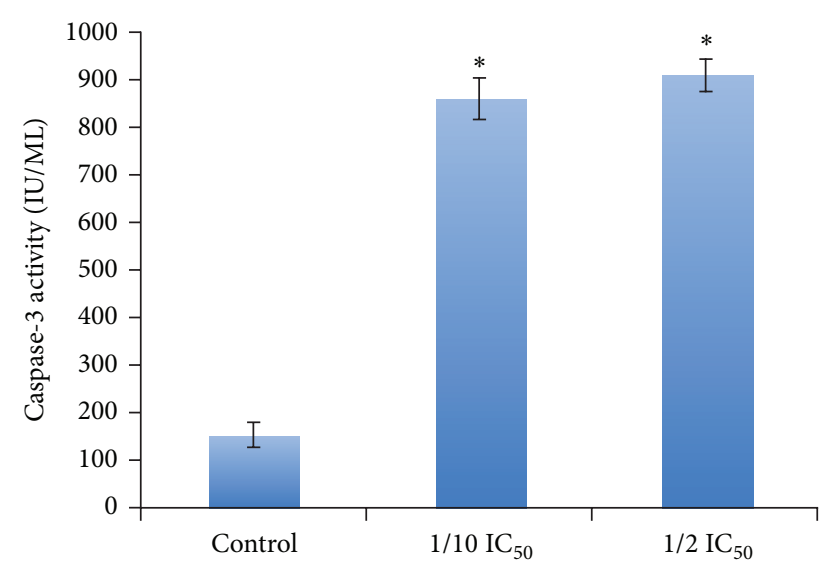

FIGURE 4: Effect of Fenugreek seed crude extract (FCE) on caspase-3 activity (as indicated by (DEVD-pNA) cleavage) of HepG2 cells. Cells were treated with or without 100 500 $\mu \mathrm{g} / \mathrm{mL}$ range of FCE for $48 \mathrm{~h}$. Cells without drug treatment were used as controls. ${ }^{*} P<0.05$ as compared to the untreated controls, using the unpaired Student $t$ test. Each data point is an average of three independent experiments and is expressed as $\mathrm{M} \pm \mathrm{SD}$. More details are under Section 2.

substrates, including poly(ADP-ribose) polymerase (PARP). The cleavage of various substrates contributes to the typical morphological and biochemical features observed in apoptosis. Because of the diversity of its substrates, caspase-3 is thought to be a general mediator of physiological and stress-induced apoptosis [41, 42]. To investigate if the FCE could be able to activate caspase- 3 in treated HepG2 cells, caspase- 3 activity was assayed according to manufacturer's protocol (more details are under Section 2) (Figure 4). Our data indicated that the FCE showed a significant increase in caspase-3 activity in treated HepG2 cells if compared with untreated cells after $48 \mathrm{~h}$. As shown in Figure 4, the FCE at the apoptosis-inducing concentration $(100 \sim 500 \mu \mathrm{g} / \mathrm{mL})$ dose strongly stimulated caspase-3-like activity in HepG2 cells. These results confirmed that FCE-induced apoptosis of HepG2 cells was in a caspase-dependent manner.

3.5. Western Blot Analysis. To investigate the intracellular mechanism for the observed increase in apoptosis in FCEtreated HepG2 cells, the protein expression levels of the p53, Bax as a well-known tumor suppressor protein and proliferating cell nuclear antigen (PCNA), an essential regulator of the cell cycle, were examined. The p53 tumor suppressor protein is a key regulator of cell cycle arrest and of apoptosis. During DNA damage, the p53 is normally activated and accumulated to exert its DNA-binding activity for the regulation of different genes that are involved in cell cycle regulation and apoptosis induction. To understand the mechanism behind the decreased cell viability after FCE treatment, we examined the p53 protein expression for different time intervals. Western blot data showed that $\mathrm{p} 53$ protein expression was upregulated after $(500 \mu \mathrm{g} / \mathrm{mL})$ FCE treatment for $48 \mathrm{~h}$ compared to untreated control cells (Figure 5(a)) and this expression was sustained till $72 \mathrm{~h}$ of treatment, suggesting that FCE treatment triggered p53 protein expression and induced apoptosis in HepG2 cells.
As PCNA is known to be a key regulator of cell cycle progression, we investigated the protein expression levels of PCNA with or without $(500 \mu \mathrm{g} / \mathrm{mL})$ FCE treatment for different time intervals. The PCNA serves as a cofactor for DNA polymerase delta in S-phase and is involved in DNA repair during DNA synthesis $[14,43]$. The temporal pattern of PCNA protein expression was upregulated and that is consistent with $\mathrm{p} 53$ expression pattern after $(500 \mu \mathrm{g} / \mathrm{mL}) \mathrm{FCE}$ treatment for 48 and $72 \mathrm{~h}$ compared to untreated control cells (Figure 5(a)). PCNA was found valuable in studying the proliferative activity in different tumors including HCC [17, 34]. Our data give clear evidence that the proliferation activity and apoptosis induction are altered by FCE treatment in HepG2 cell line. Furthermore, western blot analysis showed that the occurrence of apoptosis was confirmed by cleavage of poly(ADP-ribose) polymerase most notably at $48 \mathrm{~h}$ after $(100,500 \mu \mathrm{g} / \mathrm{mL})$ FCE treatment, which is consistent with induced significant growth inhibition (Figure 5(b); upper panel).

One of proapoptotic genes is the Bax gene that has been found to be a transcriptional target of p53, which was also determined by western blot analysis. Our data indicated that $(100,500 \mu \mathrm{g} / \mathrm{mL})$ FCE treatment for $48 \mathrm{~h}$ upregulated Bax expression by 3.1- and 3.3-fold, respectively, compared to control cells (Figure 5(b), lower panel). Taken together, our data indicated that FCE treatment induced apoptosis in HepG2 cells via arresting cells in G1 phase of cell cycle, upregulating $\mathrm{p} 53$ and proapoptotic gene, Bax, and expression levels, and increasing caspase- 3 activity.

3.6. GC-MS Analytical Data. GC-MS analysis of the bioactive constituents of the methanol extracted Trigonella foenumgraecum seeds (FCE) clearly showed the presence of fourteen compounds and their chromatogram is shown in Figure 6. Major peaks were determined in GC-MS chromatogram of FCE and their corresponding components. The active principles with their retention time (RT), molecular formula, molecular weight (MW), and concentration (peak area \%) are presented in Table 1. From the above study it may be concluded that Trigonella foenum-graecum extract contains many important phytochemicals, such as Flavonoids and Terpenoids, which play an effective role as pharmaceutical anticancer agents.

\section{Discussion}

Despite the combined efforts of governments and scientists worldwide, there is constant increase in the incidence of hepatocellular carcinoma during the last two decades [44]. Successful HCC treatment requires an adequate therapeutic index reflecting the treatment's specific effects on target cells and its lack of clinically significant effects on the host. Fenugreek is commonly used as a spice in food preparations due to the strong flavor and aroma and is used in traditional medicines as leads for therapeutic drug development in modern medicine. Pharmacological features of Fenugreek seed are known such as hypoglycaemic, hypercholesterolaemic, gastroprotective, and hepatoprotective activity $[45,46]$ and antioxidant properties against experimental cataract [47]. 
TABLE 1: Total ionic chromatogram (GC-MS) of methanol extract of Trigonella foenum-graecum, Fenugreek, obtained with $70 \mathrm{eV}$, using Elite-1 fused silica capillary column with helium gas as the carrier.

\begin{tabular}{|c|c|c|c|c|c|c|}
\hline $\mathrm{PK}$ & $\mathrm{RT}$ & Peak area & Name of the compound & Molecular formula & Molecular weight & Category of the compound \\
\hline 1 & 2.98 & 24.05 & Naringenin & $\mathrm{C}_{15} \mathrm{H}_{12} \mathrm{O}_{5}$ & 272 & Flavonoids \\
\hline 2 & 3.29 & 6.62 & Obtusifolin (anthraquinone) & $\mathrm{C}_{5} \mathrm{~N}_{11} \mathrm{~N}$ & 85 & Glycosides \\
\hline 3 & 3.38 & 6.98 & Tricin & $\mathrm{C}_{17} \mathrm{~N}_{14} \mathrm{O}_{7}$ & 330 & Flavonoids \\
\hline 4 & 6.66 & 1.87 & Vitexin & $\mathrm{C}_{21} \mathrm{H}_{20} \mathrm{O}_{10}$ & 432 & Flavonoids \\
\hline 5 & 9.91 & 3.06 & Quercetin & $\mathrm{C}_{15} \mathrm{H}_{10} \mathrm{O}_{7}$ & 330 & Flavonoids \\
\hline 6 & 12.69 & 3.04 & Limonene & $\mathrm{C}_{10} \mathrm{H}_{16}$ & 136 & Terpenoids \\
\hline 7 & 15.16 & 2.33 & Heptanoic acid & $\mathrm{C}_{9} \mathrm{H}_{18} \mathrm{O}_{2}$ & 158 & Bisphenol \\
\hline 8 & 17.40 & 3.51 & Tricine & $\mathrm{C}_{6} \mathrm{H}_{13} \mathrm{NO}_{5}$ & 179 & Flavonoids \\
\hline 9 & 17.87 & 6.77 & Kaempferol & $\mathrm{C}_{10} \mathrm{H}_{16} \mathrm{O}$ & 152 & Flavonoids \\
\hline 10 & 18.32 & 4.04 & $\gamma$-Terpinene & $\mathrm{C}_{12} \mathrm{H}_{16}$ & 132 & Terpenoids \\
\hline 11 & 19.13 & 3.51 & Carvone & $\mathrm{C}_{10} \mathrm{H}_{14} \mathrm{O}$ & 152 & Terpenoids \\
\hline 12 & 19.42 & 4.09 & 1-Tridecyne & $\mathrm{C}_{13} \mathrm{H}_{24}$ & 180 & Flavonoids \\
\hline 13 & 24.94 & 27.71 & Squalene & $\mathrm{C}_{30} \mathrm{H}_{50}$ & 410 & Terpenoids \\
\hline 14 & 31.84 & 2.42 & $\alpha$-Linolenic acid & $\mathrm{C}_{19} \mathrm{H}_{32} \mathrm{O}_{2}$ & 292 & Fatty acids \\
\hline
\end{tabular}

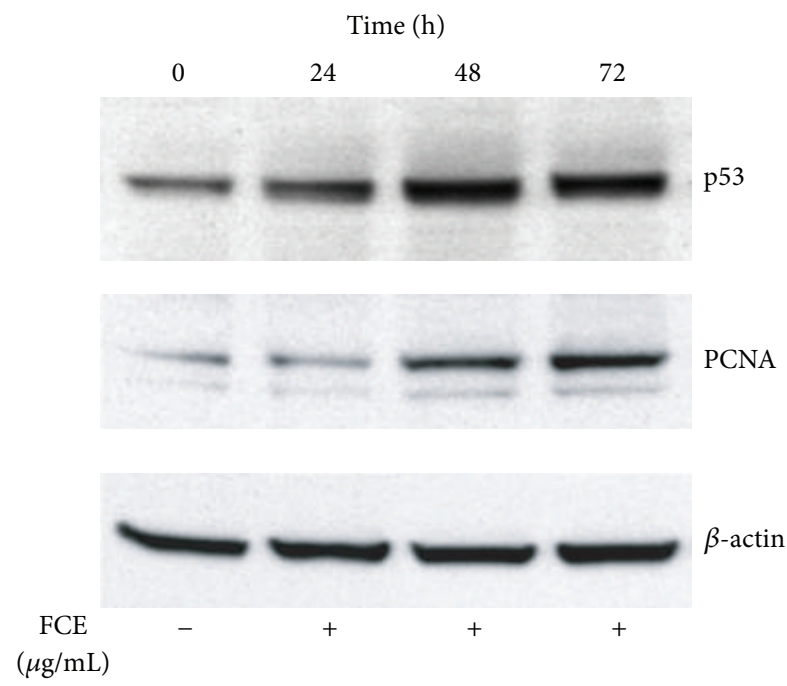

(a)

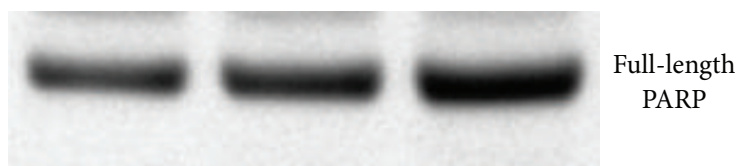

Cleaved PARP

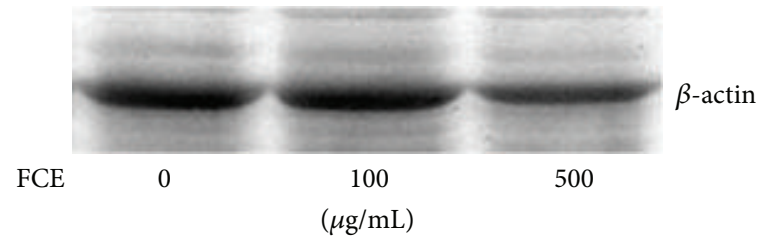

(b)

FIGURE 5: (a) Fenugreek seed crude extract (FCE) upregulated p53 and PCNA expression levels in HepG-2 cells line, using western blot analysis. Cells were treated with or without $(500 \mu \mathrm{g} / \mathrm{mL})$ FCE for different time intervals. Our data showed a significant increase in p53 and PCNA protein expression, respectively. Blots were normalized for total protein loading. Representative data from three independent experiments are shown. (b) Apoptosis indicated by poly(ADP-ribose) polymerase (PARP) cleavage. Western blot analysis for poly(ADP-ribose) polymerase (upper panel) and Bax protein expression (lower panel). Cells were treated with or without $100-500 \mu \mathrm{g} / \mathrm{mL}$ range of Fenugreek seed crude extract, FCE, for $48 \mathrm{~h}$. Blots were normalized for total protein loading.

In the present study, HepG2 cell line was selected to investigate the cytotoxicity effect of FCE on HCC. Herein, we demonstrated the cytotoxicity effect of FCE by measuring the percentage of cell mortality that was calculated by MTT assay and apoptosis induction in the HepG2 cells at different time intervals of treatment. Our data showed that FCE significantly reduced the viability of HepG2 cells in a concentration-dependent manner. The highest decrease in the cell viability of HepG2 cells was in treated cells by the $1 / 2 \mathrm{IC}_{50}$ for $48 \mathrm{~h}$. Our data agreed with the previous findings where they found difference in the sensitivity of the cell lines [48]. The reduction in percentage of cell viability after $48 \mathrm{~h}$ of treatment showed potent cytotoxic effects on HepG2 cells with FCE treatment and this effect sustained for $72 \mathrm{~h}$. Our results are also in well correlation with the previous findings in which the extract was found more cytotoxic to cancerous cells than normal cells [49] due to the sensitivity of cancerous cells towards the death flavanoids [50]. The 


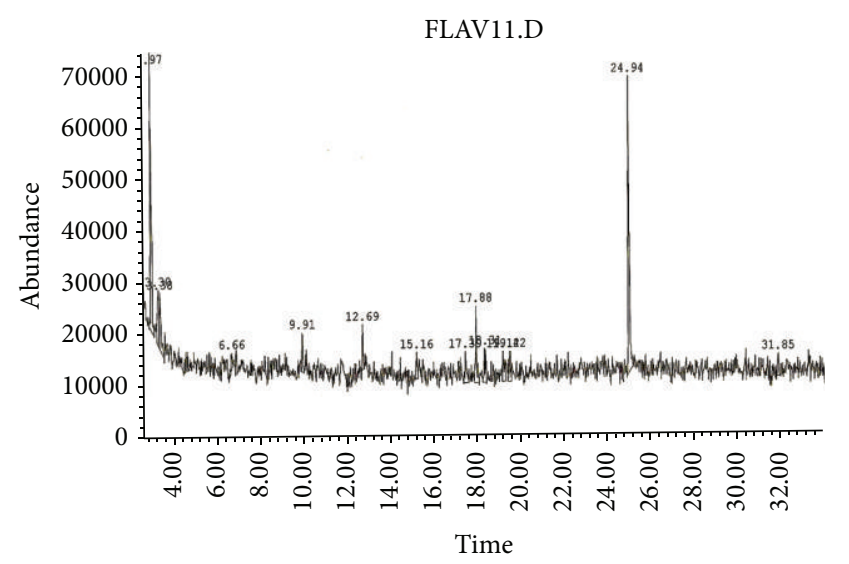

FIgURE 6: GC-MS chromatogram of methanol extract of Trigonella foenum-graecum, Fenugreek, FCE.

morphological changes in the HepG2 cells were observed more prominent in treated cells showing extensive blebbing and vacuolation, suggesting autophagic mechanism of cell death [51]. At $48 \mathrm{~h}$ of FCE treatment, HepG2 cells began to display apoptotic morphology, including shrinkage, DNA condensations, nuclear and plasma membrane convulsion, enucleation and apoptotic bodies formation, which can be seen as small masses, and nuclear fragmentation.

Modulation of the p53 gene is frequently a genetic change in different human cancers. Over $50 \%$ of all human malignancies contain mutations of p53 gene [27]. p53 has been reported to play a role in transcriptional activator to induce the transcription of many genes, including apoptosisrelated genes. One of proapoptotic genes is Bax gene that has been found to be a transcriptional target of p53 and could be upregulated in response to a variety of p53-dependent apoptosis triggers [52]. Our data demonstrates that HepG2 cells treated by FCE showed a significant increase in the protein expression levels of p53 and Bax after $48 \mathrm{~h}$, suggesting that Bax could be a transcriptional target of upregulated p53 which in turn could be responsible for inhibition of cell viability, apoptosis induction, and regulation of cell cycle related p53 genes. Previous studies also showed that diosgenin, one of the FCE active ingredients, induced apoptosis in HT-29 human colon cancer cells [23]. Furthermore, it was reported that the antiproliferative effect of diosgenin through activation of p53 could be by releasing of apoptosis-inducing factor (AIF) and modulation of caspase-3 activity in different human cancer cells [52].

In prostate cancer cells, PC-3, a cell line expressing wild type p53, FCE induced p21 expression that correlated with a cytotoxic response, suggesting a proapoptotic role for induced p21 [53]. In contrast, FCE effects are varied in different cell lines. For instance, in the mutant p53 expressing cell lines, HepG3, FCE downregulated p53 expression [54]. Furthermore, consistent with GC-MS analysis of the bioactive constituents of the methanolic extract of FCE, it was reported that FCE-induced apoptosis was mediated by the death receptor pathway, suggesting presence of some phytocompounds in FCE extract [55]. HepG2 cells express a wild type and an inducible p53 activity, as well documented previously [56], which in turn could explain the involvement of wild type upregulation in the FCE-induced apoptosis in HepG2 cell line.

Proliferating cell nuclear antigen (PCNA) is a $36 \mathrm{kDa}$ protein involved in several cellular mechanisms, including DNA synthesis and repair, cell cycle regulation, and apoptosis. An alteration in PCNA structure might contribute to DNA-damage accumulation in cancer cells. The present study was aimed at evaluating the PCNA expression pattern in HCC cell line, HepG2, after FCE treatment for different time intervals. Our data showed that PCNA protein expression was significantly increased with FCE treatment for 48 and $72 \mathrm{~h}$, respectively. The PCNA upregulation data was consistent with p53 upregulation pattern for the same period of treatment. Both by p53-dependent and -independent regulations, PCNA interacts with multiple proteins that play a key role in DNA synthesis and repair, cell cycle regulation, chromatin remodeling, and apoptosis [57].

Alterations of p53 protein have been observed during hepatocarcinogenesis [58], and the overexpression of p53 correlates with a high level of proliferation of cell nuclear antigen (PCNA), HCC dedifferentiation, and advanced HCC stages [59]. Our data showed that the treatment of HepG2 with $1 / 2$ $\mathrm{IC}_{50}$ of FCE $(500 \mathrm{~g} / \mathrm{mL})$ for 24 and $72 \mathrm{~h}$ exhibited an upregulation in the expression of both p53 and PCNA compared to the untreated control. It was expected that PCNA expression would rather be downregulated with the upregulation of p53. However, very recently, in agreement with our data, the naturally occurring selenomethionine (SeMet) upregulated the expression of p53 and PCNA and induced base excision repair (BER) activity. The distinct chemopreventive mechanism is p53-dependent and involves the binding of Gadd45a and two BER-mediated repair proteins, PCNA and apurinic/apyrimidinic endonuclease (APE1/Ref-1) [60]. Furthermore, it was reported that PCNA gene is induced by $\mathrm{p} 53$, while PCNA protein interacts with p53-controlled proteins Gadd45, MyD118, CR6, and p21, in the process of deciding cell fate [61]. The binding partner of Gadd45a can decide the activity that mediates, in other words, the binding of PCNA and $\mathrm{p} 21^{\mathrm{WAF} 1 / \mathrm{CIP} 1}$ or Cdc2 to Gadd45a can mediate DNA repair or cell cycle arrest, respectively. In addition, the possibility that p53 may be involved in the induction of human PCNA was reported earlier; the human PCNA promoter has a p53 binding site and is transactivated by wild type p53 which in turn leads to DNA repair [62]. In contrast, if PCNA is slightly upregulated in cell, apoptosis also occurs [63]. The dual role of PCNA in HepG2 cells could be explained by the presence of acidic and basic PCNA isoforms, according to previous reports $[64,65]$. The isoforms having a basic pI were exclusively found in malignant cells. The PCNA basic isoforms, exclusively detected in hepatic malignant samples, may represent a new signature for neoplastic liver cells compared to cirrhotic tissues. This finding revealed that PCNA is differently expressed in HCC, in terms of structure, isoforms, and posttranslational modifications, implicating a role for PCNA functional alterations in hepatocarcinogenesis process. 
4.1. GC-MS Analytical Data. GC-MS analysis of the bioactive constituents of the methanolic extract of FCE clearly showed the presence of fourteen bioactive compounds. Our results revealed that Squalene and Naringenin were detected as the two main components in the methanol extract of $27.71 \%$ and $24.05 \%$, respectively. In addition, the rest of components were ranged among $1.87 \%$ for butane-2,3-diol, 6.98\% for 2propen-1-amine, N-ethyl- and aziridine, and 1,2,3-trimethyltrans (6.62\%). Our results also reveal the presence of several fatty acids; in addition to many Flavonoids compounds were identified in GC-MS analysis of the Trigonella foenum seeds, including major components such as Tricin and its derivatives. Many compounds from our GC-MS analysis have anticancer activity such as Naringenin and Squalene.

Naringenin, a flavonoid that is present in high concentrations in grapefruits and citrus fruits, has a wide spectrum of pharmacological activities, including anticancer activity in primary tumor prevention [66, 67]. Furthermore, Squalene and Quercetin appear to influence several biochemical and physiological activities, which are intriguing for the treatment of cancer. Quercetin modulates the pathway toward suppression of lymphoma by downregulating PI3K-AKT1 and upregulating $\mathrm{p} 53$ pathways as well as by glycolytic metabolism [68].

\section{Conclusion}

GC-MS analysis of methanol extract of Trigonella foenumgraecum, Fenugreek seed crude extract (FCE), contains many important phytochemical, such as several fatty acids, in addition to many Flavonoids compounds, Tricin and its derivatives. Many other major compounds from our GCMS analysis have anticancer activity such as Naringenin, Quercetin, and Squalene.

The mechanism of FCE-induced cell death was via inhibiting HepG2 cell viability and inducing apoptosis. FCE enhances apoptosis induction in HepG2 cell in p53, Bax and PCNA-dependent pathway, and G1 phase arrest that was confirmed by cell cycle analysis. Despite the finding of p53 involvement in FCE cell viability inhibition and apoptosis induction, the exact downstream target of p53 is unclear, which requires further investigation. However, we suggest that induction of p53, Bax, and PCNA-dependent pathway which mediated apoptosis with caspase- 3 activation is, at least in part, a possible explanation for the anti-liver-carcinogenic effect of FCE which in turn might be a potential strategy for HCC treatment.

\section{Conflict of Interests}

The authors declare that they have no conflict of interests.

\section{Acknowledgment}

The authors would like to extend their sincere appreciation to the Deanship of Scientific Research at King Saud University for its funding of this research through the Research Group Project no. RGP-VPP-297.

\section{References}

[1] J. Ferlay, I. Soerjomataram, R. Dikshit et al., "Cancer incidence and mortality worldwide: sources, methods and major patterns in GLOBOCAN 2012," International Journal of Cancer, vol. 136, no. 5, pp. E359-E386, 2015.

[2] K. A. McGlynn, L. Tsao, A. W. Hsing, S. S. Devesa, and J. F. Fraumeni Jr., "International trends and patterns of primary liver cancer," International Journal of Cancer, vol. 94, no. 2, pp. 290296, 2001.

[3] M. K. Shaker, H. M. Abdella, M. O. Khalifa, and A. K. E. Dorry, "Epidemiological characteristics of hepatocellular carcinoma in Egypt: a retrospective analysis of 1313 cases," Liver International, vol. 33, no. 10, pp. 1601-1606, 2013.

[4] N. Abdel-Hamid, "Update to risk factors of HCC," International Journal of Medicine and Medical Sciences, vol. 1, no. 3, pp. 38-43, 2009.

[5] A. S. Sultan, J. Xie, M. J. LeBaron, E. L. Ealley, M. T. Nevalainen, and H. Rui, "Stat5 promotes homotypic adhesion and inhibits invasive characteristics of human breast cancer cells," Oncogene, vol. 24, no. 5, pp. 746-760, 2005.

[6] A. S. Sultan, H. Brim, and Z. A. Sherif, "Co-overexpression of Janus kinase 2 and signal transducer and activator of transcription 5a promotes differentiation of mammary cancer cells through reversal of epithelial-mesenchymal transition," Cancer Science, vol. 99, no. 2, pp. 272-279, 2008.

[7] J. Sun and R. Hai Liu, "Cranberry phytochemical extracts induce cell cycle arrest and apoptosis in human MCF-7 breast cancer cells," Cancer Letters, vol. 241, no. 1, pp. 124-134, 2006.

[8] A. S. Sultan and Z. A. Sherif, "Abstract B42: Jak2/Stat5a overexpression synergizes with mistletoe (Viscum album) extracts, and/or diallyl trisulfide (DATS) to inhibit breast cancer stem cell characteristics, epithelial-mesenchymal transition, and invasion potential," Molecular Cancer Therapeutics, vol. 10, supplement 11, p. B42, 2011.

[9] K. H. Kwon, A. Barve, S. Yu, M.-T. Huang, and A.-N. T. Kong, "Cancer chemoprevention by phytochemicals: potential molecular targets, biomarkers and animal models," Acta Pharmacologica Sinica, vol. 28, no. 9, pp. 1409-1421, 2007.

[10] O. R. Omobuwajo, A. Abdu, O. A. Igbeneghu, I. O. Agboola, and G. O. Alade, "Preliminary investigation of herbal soap incorporating Cassia senna (L) Roxb leaves and Ageratum conyzoides linn whole plant powders," Continental Journal of Pharmaceutical Sciences, vol. 5, pp. 1-10, 2011.

[11] C. W. Fetrow and J. R. Avila, Professional's Handbook of Complementary \& Alternative Medicines, Springhouse Corporation, Spring House, Pa, USA, 1999.

[12] R. Mebazaa, A. Mahmoudi, M. Fouchet et al., "Characterisation of volatile compounds in Tunisian fenugreek seeds," Food Chemistry, vol. 115, no. 4, pp. 1326-1336, 2009.

[13] M. M. Naidu, B. N. Shyamala, J. Pura Naik, G. Sulochanamma, and P. Srinivas, "Chemical composition and antioxidant activity of the husk and endosperm of fenugreek seeds," LWT-Food Science and Technology, vol. 44, no. 2, pp. 451-456, 2011.

[14] W. G. Taylor, M. S. Zaman, Z. Mir et al., "Analysis of steroidal sapogenins from Amber Fenugreek (Trigonella foenumgraecum) by capillary gas chromatography and combined gas chromatography/mass spectrometry," Journal of Agricultural and Food Chemistry, vol. 45, no. 3, pp. 753-759, 1997. 
[15] Y. Wu, W. Cui, N. A. M. Eskin, and H. D. Goff, "An investigation of four commercial galactomannans on their emulsion and rheological properties," Food Research International, vol. 42, no. 8, pp. 1141-1146, 2009.

[16] G. S. Kumar, A. K. Shetty, K. Sambaiah, and P. V. Salimath, "Antidiabetic property of fenugreek seed mucilage and spent turmeric in streptozotocin-induced diabetic rats," Nutrition Research, vol. 25, no. 11, pp. 1021-1028, 2005.

[17] T. Goswami, "A review on the functional properties, nutritional content, medicinal utilization and potential application of fenugreek," Journal of Food Processing \& Technology, vol. 3, no. 9, pp. 1-10, 2012.

[18] K. Bhatia, M. Kaur, F. Atif et al., "Aqueous extract of Trigonella foenum-graecum L. ameliorates additive urotoxicity of buthionine sulfoximine and cyclophosphamide in mice," Food and Chemical Toxicology, vol. 44, no. 10, pp. 1744-1750, 2006.

[19] K. K. Khoja, G. Shafi, T. N. Hasan et al., "Fenugreek, a naturally occurring edible spice, kills MCF-7 human breast cancer cells via an apoptotic pathway," Asian Pacific Journal of Cancer Prevention, vol. 12, no. 12, pp. 3299-3304, 2011.

[20] J. E. Thomas, M. Bandara, E. L. Lee, D. Driedger, and S. Acharya, "Biochemical monitoring in fenugreek to develop functional food and medicinal plant variants," New Biotechnology, vol. 28, no. 2, pp. 110-117, 2011.

[21] A. Amin, A. Alkaabi, S. Al-Falasi, and S. A. Daoud, "Chemopreventive activities of Trigonella foenum graecum (Fenugreek) against breast cancer," Cell Biology International, vol. 29, no. 8, pp. 687-694, 2005.

[22] S. F. S. Reihani and M. E. Azhar, "Antioxidant activity and total phenolic content in aqueous extracts of selected traditional mlay salads (Ulam)," International Food Research Journal, vol. 19, no. 4, pp. 1439-1444, 2012.

[23] J. Raju, J. M. R. Patlolla, M. V. Swamy, and C. V. Rao, "Diosgenin, a steroid saponin of Trigonella foenum graecum (Fenugreek), inhibits azoxymethane-induced aberrant crypt foci formation in F344 rats and induces apoptosis in HT-29 human colon cancer cells," Cancer Epidemiology Biomarkers and Prevention, vol. 13, no. 8, pp. 1392-1398, 2004.

[24] S. Shishodia and B. B. Aggarwal, "Diosgenin inhibits osteoclastogenesis, invasion, and proliferation through the downregulation of Akt, I $\kappa \mathrm{B}$ kinase activation and NF- $\kappa \mathrm{B}$-regulated gene expression," Oncogene, vol. 25, no. 10, pp. 1463-1473, 2006.

[25] R. D. Bhalke, S. J. Anarthe, K. D. Sasane, S. N. Satpute, S. N. Shinde, and V. S. Sangle, "Antinociceptive activity of Trigonella foenum-graecum leaves and seeds (Fabaceae)," Iranian Journal of Pharmacology \& Therapeutics, vol. 8, no. 2, pp. 57-59, 2009.

[26] H. Hibasami, H. Moteki, K. Ishikawa et al., "Protodioscin isolated from fenugreek (Trigonella foenum graecum L.) induces cell death and morphological change indicative of apoptosis in leukemic cell line $\mathrm{H}-60$, but not in gastric cancer cell line KATO III," International Journal of Molecular Medicine, vol. 11, no. 1, pp. 23-26, 2003.

[27] Q. Yu, "Restoring p53-mediated apoptosis in cancer cells: new opportunities for cancer therapy," Drug Resistance Updates, vol. 9, no. 1-2, pp. 19-25, 2006.

[28] K. H. Vousden and X. Lu, "Live or let die: the cell's response to p53," Nature Reviews Cancer, vol. 2, no. 8, pp. 594-604, 2002.

[29] I. O. L. Ng, E. C. S. Lai, A. S. Y. Chan, and M. K. P. So, "Overexpression of p53 in hepatocellular carcinomas: a clinicopathological and prognostic correlation," Journal of Gastroenterology and Hepatology, vol. 10, no. 3, pp. 250-255, 1995.
[30] K. Breuhahn, T. Longerich, and P. Schirmacher, "Dysregulation of growth factor signaling in human hepatocellular carcinoma," Oncogene, vol. 25, no. 27, pp. 3787-3800, 2006.

[31] F. Farinati, D. Marino, M. De Giorgio et al., "Diagnostic and prognostic role of $\alpha$-fetoprotein in hepatocellular carcinoma: both or neither?" The American Journal of Gastroenterology, vol. 101, no. 3, pp. 524-532, 2006.

[32] G. Guzman, V. Alagiozian-Angelova, J. E. Layden-Almer et al., "p53, Ki-67, and serum alpha feto-protein as predictors of hepatocellular carcinoma recurrence in liver transplant patients," Modern Pathology, vol. 18, no. 11, pp. 1498-1503, 2005.

[33] I. Stoimenov and T. Helleday, "PCNA on the crossroad of cancer," Biochemical Society Transactions, vol. 37, part 3, pp. 605-613, 2009.

[34] G. Loor, S.-J. Zhang, P. Zhang, N. Lan Toomey, and M. Y. W. T. Lee, "Identification of DNA replication and cell cycle proteins that interact with PCNA," Nucleic Acids Research, vol. 25, no. 24, pp. 5041-5046, 1997.

[35] S.-C. Wang, Y. Nakajima, Y.-L. Yu et al., "Tyrosine phosphorylation controls PCNA function through protein stability," Nature Cell Biology, vol. 8, no. 12, pp. 1359-1368, 2006.

[36] S. N. Naryzhny and H. Lee, "The post-translational modifications of proliferating cell nuclear antigen: acetylation, not phosphorylation, plays an important role in the regulation of its function," The Journal of Biological Chemistry, vol. 279, no. 19, pp. 20194-20199, 2004.

[37] D. J. Hoelz, R. J. Arnold, L. E. Dobrolecki et al., “The discovery of labile methyl esters on proliferating cell nuclear antigen by MS/MS," Proteomics, vol. 6, no. 17, pp. 4808-4816, 2006.

[38] S.-H. Peng, J.-F. Yang, P.-P. Xie, H. Deng, H. Li, and D.-Y. Feng, "Expression of cyclins in hepatocellular carcinoma and its correlation to tumor cell apoptosis," Chinese Journal of Cancer, vol. 24, no. 6, pp. 695-698, 2005.

[39] A. Ashkenazi and V. M. Dixit, "Death receptors: signaling and modulation," Science, vol. 281, no. 5381, pp. 1305-1308, 1998.

[40] M. D. Jacobson, M. Weil, and M. C. Raff, "Programmed cell death in animal development," Cell, vol. 88, no. 3, pp. 347-354, 1997.

[41] X. Liu, H. Zou, C. Slaughter, and X. Wang, "DFF, a heterodimeric protein that functions downstream of caspase-3 to trigger DNA fragmentation during apoptosis," Cell, vol. 89, no. 2, pp. 175-184, 1997.

[42] R. Datta, H. Kojima, K. Yoshida, and D. Kufe, "Caspase3-mediated cleavage of protein kinase $\mathrm{C} \theta$ in induction of apoptosis," The Journal of Biological Chemistry, vol. 272, no. 33, pp. 20317-20320, 1997.

[43] R. Bravo and H. Macdonald-Bravo, "Existence of two populations of cyclin/proliferating cell nuclear antigen during the cell cycle: association with DNA replication sites," The Journal of Cell Biology, vol. 105, no. 4, pp. 1549-1554, 1987.

[44] H. B. El-Serag, "Hepatocellular carcinoma: recent trends in the United States," Gastroenterology, vol. 127, supplement 1, no. 5, pp. S27-S34, 2004.

[45] V. Thirunavukkarasu, C. V. Anuradha, and P. Viswanathan, "Protective effect of fenugreek (Trigonella foenum graecum) seeds in experimental ethanol toxicity," Phytotherapy Research, vol. 17, no. 7, pp. 737-743, 2003.

[46] S. Kaviarasan and C. V. Anuradha, "Fenugreek (Trigonella foenum graecum) seed polyphenols protect liver from alcohol toxicity: a role on hepatic detoxification system and apoptosis," Die Pharmazie, vol. 62, no. 4, pp. 299-304, 2007. 
[47] S. K. Gupta, V. Kalaiselvan, S. Srivastava, R. Saxena, and S. S. Agrawal, "Trigonella foenum-graecum (fenugreek) protects against selenite-induced oxidative stress in experimental cataractogenesis," Biological Trace Element Research, vol. 136, no. 3, pp. 258-268, 2010.

[48] P. Vijayan, P. Vijayaraj, P. H. C. Setty et al., "The cytotoxic activity of the total alkaloids isolated from different parts of Solanum pseudocapsicum," Biological and Pharmaceutical Bulletin, vol. 27, no. 4, pp. 528-530, 2004.

[49] S. Vijayarathna and S. Sasidharan, "Cytotoxicity of methanol extracts of Elaeis guineensis on MCF-7 and Vero cell lines," Asian Pacific Journal of Tropical Biomedicine, vol. 2, no. 10, pp. 826-829, 2012.

[50] A. Das, N. L. Banik, and S. K. Ray, "Flavonoids activated caspases for apoptosis in human glioblastoma T98G and U87MG cells but not in human normal astrocytes," Cancer, vol. 116, no. 1, pp. 164-176, 2010.

[51] G. McGill and D. E. Fisher, "Apoptosis in tumorigenesis and cancer therapy," Frontiers in Bioscience, vol. 2, pp. 353-379, 1997.

[52] C. Corbiere, B. Liagre, F. Terro, and J.-L. Beneytout, "Induction of antiproliferative effect by diosgenin through activation of p53, release of apoptosis-inducing factor (AIF) and modulation of caspase-3 activity in different human cancer cells," Cell Research, vol. 14, no. 3, pp. 188-196, 2004.

[53] R. Aneja, A. M. Ghaleb, J. Zhou, V. W. Yang, and H. C. Joshi, "p53 and p21 determine the sensitivity of noscapine-induced apoptosis in colon cancer cells," Cancer Research, vol. 67, no. 8, pp. 3862-3870, 2007.

[54] M. Cordenonsi, M. Montagner, M. Adorno et al., "Integration of TGF- $\beta$ and Ras/MAPK signaling through p53 phosphorylation," Science, vol. 315, no. 5813, pp. 840-843, 2007.

[55] A. A. Alshatwi, G. Shafi, T. N. Hasan, N. A. Syed, and K. K. Khoja, "Fenugreek induced apoptosis in breast cancer MCF7 cells mediated independently by fas receptor change," Asian Pacific Journal of Cancer Prevention, vol. 14, no. 10, pp. 57835788, 2013.

[56] K. Boehme, Y. Dietz, P. Hewitt, and S. O. Mueller, "Activation of P53 in HepG2 cells as surrogate to detect mutagens and promutagens in vitro," Toxicology Letters, vol. 198, no. 2, pp. 272281, 2010.

[57] G. Maga and U. Hübscher, "Proliferating cell nuclear antigen (PCNA): a dancer with many partners," Journal of Cell Science, vol. 116, no. 15, pp. 3051-3060, 2003.

[58] M. R. Hussein, "Alterations of p53, Bcl-2, and hMSH2 protein expression in the cirrhotic, macroregenerative, dysplastic nodules and hepatocellular carcinomas in Upper Egypt," Liver International, vol. 24, no. 6, pp. 552-560, 2004.

[59] T.-H. Hu, C.-C. Wang, C.-C. Huang et al., "Down-regulation of tumor suppressor gene PTEN, overexpression of p53, plus high proliferating cell nuclear antigen index predict poor patient outcome of hepatocellular carcinoma after resection," Oncology Reports, vol. 18, no. 6, pp. 1417-1426, 2007.

[60] H. J. Jung, H. L. Kim, Y. J. Kim, J.-I. Weon, and Y. R. Seo, "A novel chemopreventive mechanism of selenomethionine: enhancement of APE1 enzyme activity via a Gadd45a, PCNA and APE1 protein complex that regulates p53-mediated base excision repair," Oncology Reports, vol. 30, no. 4, pp. 1581-1586, 2013.

[61] N. Azam, M. Vairapandi, W. Zhang, B. Hoffman, and D. A. Liebermann, "Interaction of CR6 (GADD45 $\gamma$ ) with proliferating cell nuclear antigen impedes negative growth control," The
Journal of Biological Chemistry, vol. 276, no. 4, pp. 2766-2774, 2001.

[62] H.-W. Chang, Y.-C. Lai, C.-Y. Cheng, J.-L. Ho, S.-T. Ding, and Y.C. Liu, "UV inducibility of rat proliferating cell nuclear antigen gene promoter," Journal of Cellular Biochemistry, vol. 73, no. 3, pp. 423-432, 1999.

[63] C. V. Shivakumar, D. R. Brown, S. Deb, and S. P. Deb, "Wild-type human p53 transactivates the human proliferating cell nuclear antigen promoter," Molecular and Cellular Biology, vol. 15, no. 12, pp. 6785-6793, 1995.

[64] T. Paunesku, S. Mittal, M. Protić et al., "Proliferating cell nuclear antigen (PCNA): ringmaster of the genome," International Journal of Radiation Biology, vol. 77, no. 10, pp. 1007-1021, 2001.

[65] S. N. Naryzhny and H. Lee, "Observation of multiple isoforms and specific proteolysis patterns of proliferating cell nuclear antigen in the context of cell cycle compartments and sample preparations," Proteomics, vol. 3, no. 6, pp. 930-936, 2003.

[66] L. Le Marchand, S. P. Murphy, J. H. Hankin, L. R. Wilkens, and L. N. Kolonel, "Intake of flavonoids and lung cancer," Journal of the National Cancer Institute, vol. 92, no. 2, pp. 154-160, 2000.

[67] S.-I. Kanno, A. Tomizawa, T. Hiura et al., "Inhibitory effects of naringenin on tumor growth in human cancer cell lines and sarcoma S-180-implanted mice," Biological and Pharmaceutical Bulletin, vol. 28, no. 3, pp. 527-530, 2005.

[68] A. K. Maurya and M. Vinayak, "Quercetin regresses Dalton's lymphoma growth via suppression of PI3K/AKT signaling leading to upregulation of p53 and decrease in energy metabolism," Nutrition and Cancer, vol. 67, no. 2, pp. 354-363, 2015. 


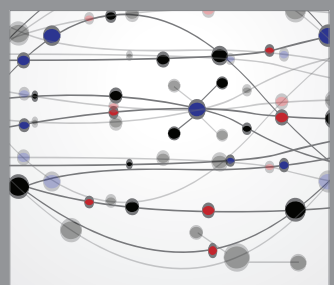

The Scientific World Journal
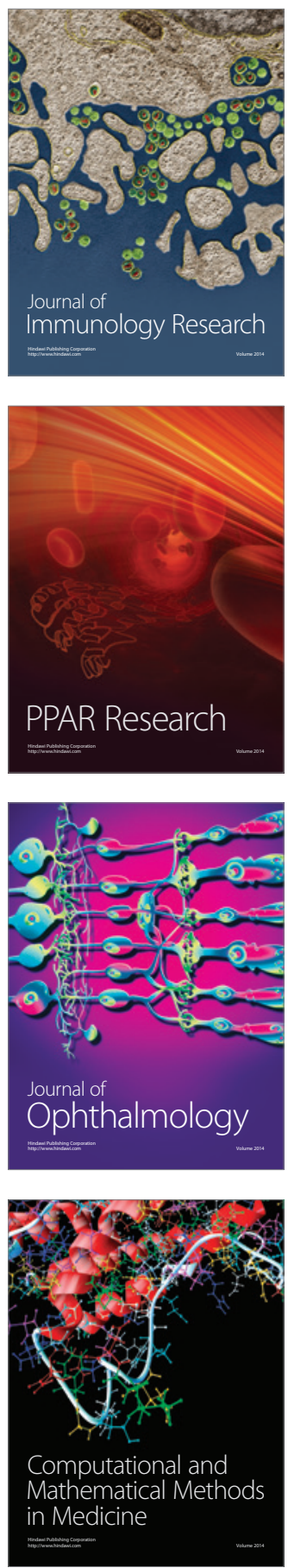

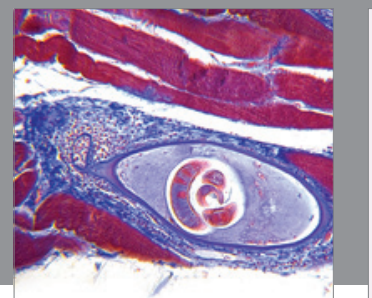

Gastroenterology

Research and Practice
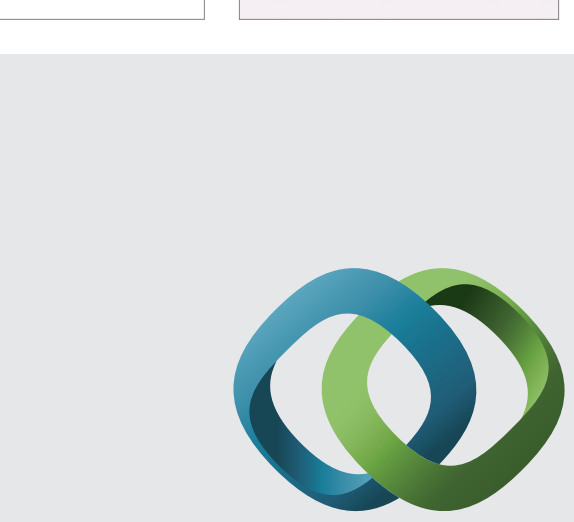

\section{Hindawi}

Submit your manuscripts at

http://www.hindawi.com
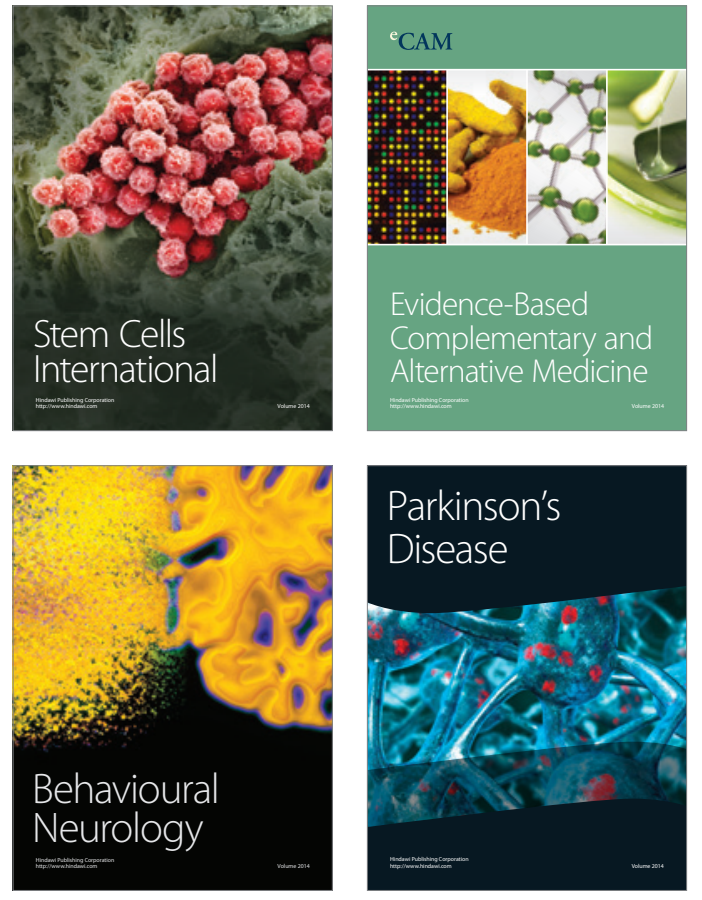
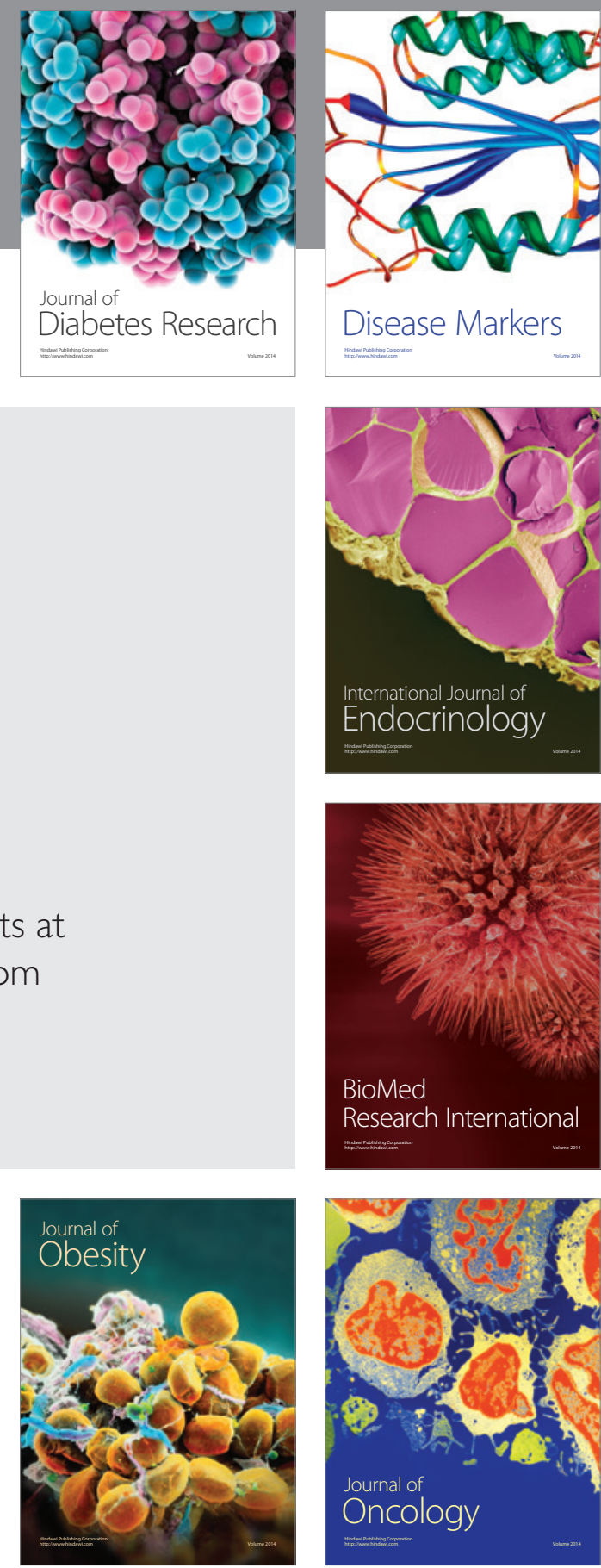

Disease Markers
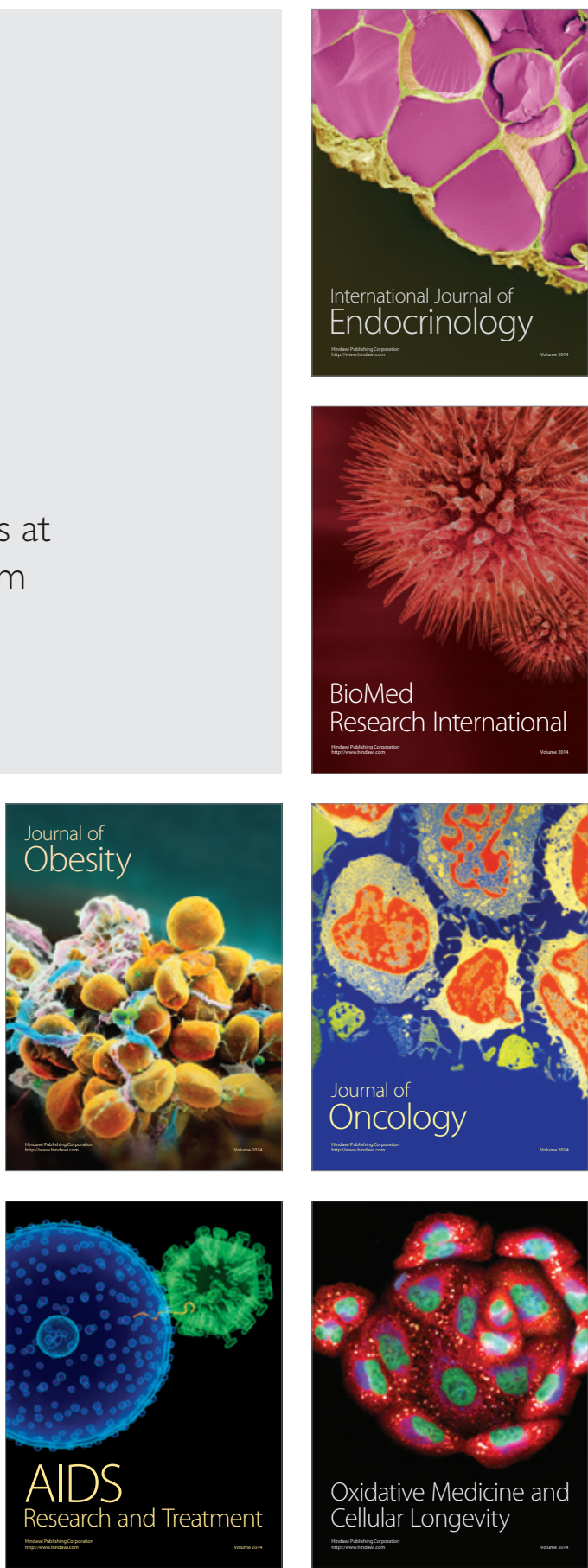